\title{
Effects of Picture Prompts on Story Retelling Performance in Typically Developing Children
}

\author{
Efeitos de Dicas Visuais no Desempenho de Recontagem de Histórias \\ em Crianças com Desenvolvimento Típico
}

\author{
Ana Carolina Sella ${ }^{*}, a$, Carmen Silvia Motta Bandini ${ }^{b, f}$, Heloísa Helena Motta Bandini ${ }^{c, f}$, \\ Daniela Mendonça Ribeiro ${ }^{d} \&$ Hilton Caio Vieira ${ }^{e}$ \\ ${ }^{a}$ University of Nebraska Medical Center, Omaha, NE, United States of America, \\ ${ }^{b}$ Centro Universitário CESMAC, Maceió, AL, Brasil, \\ ${ }^{c}$ Universidade Estadual de Ciências da Saúde do Alagoas, Maceió, AL, Brasil, \\ ${ }^{d}$ Universidade Federal de Alagoas, Maceió, AL, Brasil \& \\ ${ }^{e}$ Universidade Federal da Grande Dourados, Dourados, MS, Brasil \\ Instituto Nacional de Ciência e Tecnologia sobre Comportamento Cognição e Ensino INCT- ECCE
}

\begin{abstract}
Telling and retelling stories and facts are behavioral repertoires that are constantly recruited in social situations, no matter if these situations occur at school, with the family, or at leisure times. This study aimed at systematically evaluating if 11 first graders (age range six to seven), would perform better in retelling tasks when pictorial prompts were presented. Dependent variables were (a) number of story categories inserted in the retelling tasks and (b) number of retold words per story. The independent variable was the presentation of visual prompts during story retelling tasks. Results indicated that visual prompts did not result in consistent increase in performance when the number of story categories inserted was analyzed. Additionally, there was no consistent increase in the number of words retold when pictures were presented. Future studies should investigate whether repeated exposure to stories would result in a significant change in performance. Keywords: Story retelling, children, pictures, visual prompts.
\end{abstract}

\begin{abstract}
Resumo
Contar e recontar histórias e fatos são repertórios comportamentais constantemente necessários em situações sociais, sejam estas escolares, familiares, ou de lazer. Este estudo buscou avaliar sistematicamente se 11 alunos de primeira série (idades entre seis e sete anos) teriam melhor desempenho em tarefas de recontagem de histórias quando dicas visuais eram apresentadas. As variáveis dependentes foram (a) número de categorias de história inseridas nas tarefas de recontagem e (b) número de palavras recontadas por história. A variável independente foi a apresentação de dicas visuais (figuras) nas tarefas de recontagem. Os resultados indicaram que dicas visuais não resultaram em melhora de desempenho quando o número de categorias de história foi analisado. Também foi verificado que não houve aumento consistente no número de palavras recontadas quando as figuras foram apresentadas. Estudos futuros devem investigar se a reexposição a histórias resultaria em uma mudança significativa no desempenho.

Palavras-chave: Recontagem de história, crianças, figuras, dicas visuais.
\end{abstract}

Telling and retelling stories and facts are behavioral repertoires that are constantly recruited in people's lives:

\footnotetext{
" Mailing address: Av. Dr. Antonio Gouveia, 475, apt 206. Maceió, AL - 57030-170. Phone number: (5582) 8137-2212. E-mail: carolsella@gmail.com

Acknowledgment: Thalyta de Souza Rodrigues (UNCISAL-AL)

Support: Alagoas Research Foundation (FAPEAL). Instituto Nacional de Ciência e Tecnologia sobre Comportamento, Cognição e Ensino with resources from São Paulo Research Foundation (FAPESP - Grant \# 2008/57705-8); and National Council for Scientific and Technological Development $(\mathrm{CNPq}$ - Grant \# 573972/2008-7).
}

people ask each other about their days, make conversation about facts that occurred in their lives, and create fictional stories to entertain other people (McCabe, Bliss, Barra, \& Bennett, 2008; Stein, 1982). In educational settings, the behavioral repertoires of creating and reproducing stories orally or in writing are also constantly recruited. Learning these skills is described as a permanent issue by the Brazilian National Curriculum Standards (Secretaria de Educação Fundamental, 1998). These standards propose, as clear objectives for Education, that elementary and middle school students should learn how to use language when listening to different types of essays, when generating 
essays, and when structuring experience to explain reality. Even though these repertoires might be treated as a single unit, they are comprised of several elements, such as use of story grammar categories (Mandler \& Johnson, 1977), story length (Merritt \& Liles, 1987), and fluency (Roberts, Good, \& Corcoran, 2005). For an audience to appraise a given story (re)telling performance as "good" all of these elements must come under appropriate stimulus control (Ribeiro, Pascualon, Sella, Bandini, \& de Souza, 2009).

The investigation of the acquisition of telling and retelling story behaviors is important due to two main aspects. One refers to a practical issue and one to the scientific issues involved. In regards to the practical issue, it is a fact that many Brazilian students perform poorly in tasks that require reading comprehension and essay production. For example, in the latest Programme for International Student Assessment (PISA), conducted in 2012 (Organization for Economic Cooperation and Development, 2013), the performance of Brazilian students was ranked $55^{\text {th }}$ in the language assessment among the 65 countries that participated. In regards to the scientific issues, approaches to education and behavior that have a solid body of research on programming and implementing efficacious teaching procedures, such as Behavior Analysis, have very few studies that focus on developing teaching procedures aiming at these skills. Behavior analytical procedures have been successfullty teaching complex behavior (e.g., Fienup, Covey, \& Critchfield, 2010) and could be systematically used to teach (re)telling behaviors. One tool that has been extensively used within the behavior analytic literature to teach complex behaviors is the use of pictorial prompts: studies have used pictorial prompts to establish a variety of behavioral repertoires such as computer skills (Frank, Wacker, Berg, \& McMahon, 1985) and intraverbals (Ingvarsson \& Hollobaugh, 2011). Despite the paucity of studies that specifically investigated the establishment of telling and retelling behaviors under the control of pictorial prompts, behavior analytic studies describe several variables that might be involved in the establishment of behavioral repertoires - such as the ones mentioned above - under the control of pictorial prompts. These variables include requesting observational responses to the pictorial prompts, use of least-to-most prompts, reinforcement for emitting an observational response to the pictorial prompts, reinforcement for correct responses, and error correction procedures. Additionally, studies such as those conducted by Phillips and Vollmer (2012) also investigated variables involved in generalized pictorial instruction following, suggesting that varying the sequence in which the pictures are presented contributes to response generalization to new sets of prompts. The results described by behavior analytic studies provide the foundation for an investigation aiming at describing variables involved in the establishment of telling and retelling behaviors.

When the cognitive literature is searched, one will find a different scenario in regards to the establishment of telling and retelling behaviors when compared to the behavior analytic literature: many studies within the cognitive approach have specifically investigated the effects of visual - more specifically pictorial - prompts on telling and retelling tasks (Gabig, 2008; Lins e Silva \& Spinillo, 2000). Participants in these studies varied from preschoolers (less than 3 years of age) to late adults ( 82 years of age) whose mean years of education varied from zero to 23. Even though participants' characteristics and part of their repertoire has been described in these studies, there are no descriptions on how to establish telling and retelling behaviors under the control of pictorial prompts. In most of these studies, the effects of pictorial prompts were evaluated under test conditions: no reinforcement was programmed for correct performances in which picture prompts were presented (Lins e Silva \& Spinillo, 2000). Sometimes, not even instruction was provided regarding the use of prompts (Gabig, 2008). In their discussion and conclusion sections, many of these studies assert that the use of pictural prompts results in better performance in telling and retelling tasks when compared to control groups in which no pictorial prompt is presented; however there is no discussion about how telling and retelling behavior becomes controlled by pictorial prompts in terms of environmental manipulations. As discussed by Phillips and Vollmer (2012), from a behavioral perspective, one could infer that for these behaviors to occur, the participants would have to have had a history with pictorial prompts that resulted in the establishment of a generalized control of telling and retelling tasks by such prompts. Additionally, most studies do not systematically describe how many times each story was presented, how and where prompts were presented, and instructions given during retelling tasks.

Given that behavior analytic studies do not seem to have used pictorial prompts to establish telling and retelling behaviors, and given that cognitivist studies have not thoroughly and systematically described the procedures used to evoke such repertoires, the present study aimed at systematically evaluating if 11 first graders would perform better in retelling tasks when pictorial prompts were present but no reinforcement was provided for correct responses, and no explicit instructions were provided for using the prompts. The purpose of this investigation was to test if the results shown in cognitive studies would be replicated with the participants of the current study. If participants' performance was better in the presence of pictorial prompts, then, more evidence would have been accrued in regards to stating that young children, with very little school experience already have a generalized repertoire of using such prompts when following the instruction to retell a story. If participants did not perform consistently with a generalized repertoire, next steps for establishing these repertoires would be proposed. The general hypothesis was that given the lack of a history of reinforcement with the contingencies, the presence of 
Sella, A. C., Bandini, C. S. M., Bandini, H. H. M., Ribeiro, D. M. \& Vieira, H. C. (2015). Effects of Picture Prompts on Story Retelling Performance in Typically Developing Children.

pictorial prompts would not result in better performance in retelling tasks.

This type of investigation can result in advances in regards to uncovering prerequisite behaviors that are important for the acquisition and programming of efficient teaching procedures in story retelling, especially for students that have not been successful in acquiring these repertoires through regular education in schools.

\section{Method}

\section{Participants}

Eleven first graders (age range 6 to 7 years of age), seven girls and four boys, took part in the study. Participants were designated by the school administration and teacher and did not have any hearing or visual loss that would interfere with their performance. Participants' parents signed an informed consent as approved by the ethics committee of the university whose researchers implemented the procedures.

\section{Experimental Materials, Setting, and Stimuli}

A digital voice recorder was used to record all sessions. A teddy bear was used as the naïve listener. According to the literature, naïve listeners are important because children tend to assume mutual knowledge and omit details when they are telling a story to someone who either told them the story or listened to the story with them (Kail \& Hickmann, 1992; Liles, 1985). However, a naïve listener might not be available in all settings, thus studies have used puppets and other characters as the naïve listener (Sparks, 2008). Due to the fact that we had only one person available to be at the school, we used a teddy bear as a resource for our retelling tasks. Additionally, games and coloring activities were available at the end of each session. Access to these activities was independent of performance.

Sessions were conducted in a classroom in the participants' school. The experimenter arranged two desks and three chairs close to each other. One chair was used by the participant, one by the experimenter, and the third chair remained empty until the teddy bear was brought out from the back of the classroom.

There were two sets of experimental stimuli. The first one was comprised of eight audio stories written by the authors and presented by a laptop computer (the number of words in the stories ranged from 145 to 190 words). All eight stories contained six story categories (characters $-\mathrm{C}$, setting $-\mathrm{S}$, time $-\mathrm{T}$, problem $-\mathrm{P}$, actions $-\mathrm{A}$, and resolution $-\mathrm{R}$ ) and were designed to have character, place, and time appear twice per story, and problem, actions, and resolution appear once in each story. None of the stories contained words that explicitly identified the categories (Sella, Ribeiro, Bandini, Bandini, \& Bonfim, 2013). The other set of stimuli was comprised by six color printed pictures that illustrated the different six story categories (character, setting, time, problem, actions, and resolution). Hereafter these pictures will be designated as visual prompts. Figure 1 depicts how the visual prompts were presented throughout the sessions.

\section{Dependent and Independent Variables}

The dependent variables of this study were (a) number of story categories inserted in the retelling tasks and (b) number of retold words in relation to the total number of words in each story. The independent variable was the presentation of visual prompts during story retelling tasks.

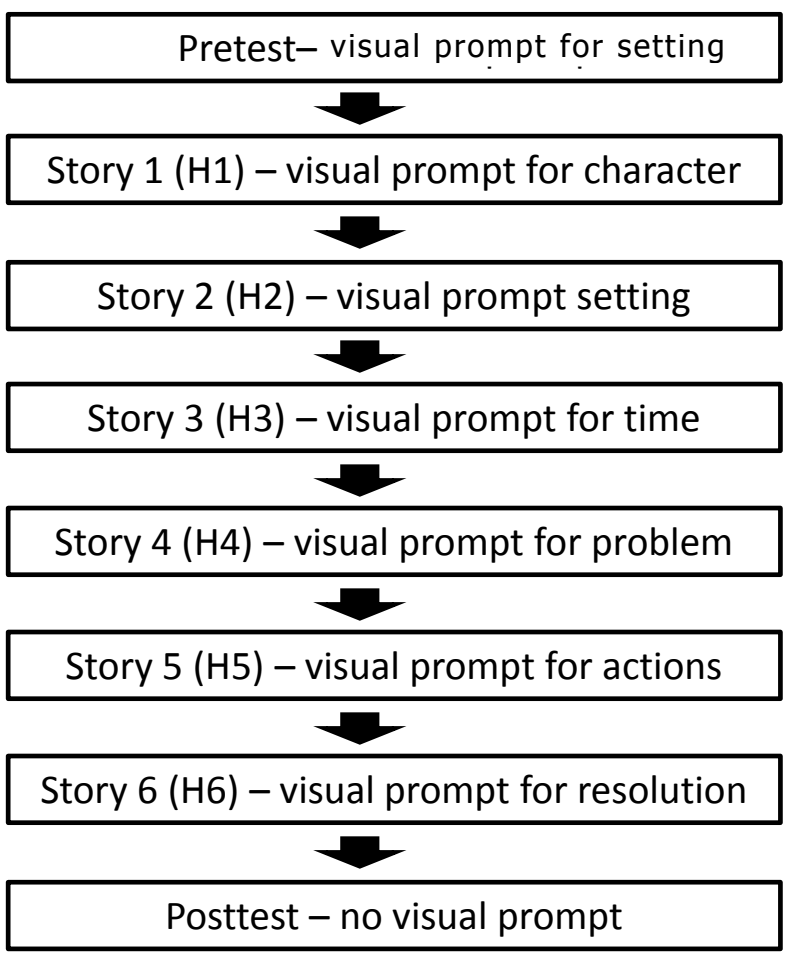

Figure 1. Presence or absence of picture prompts in each story

\section{Experimental Design}

A multiple probe design across categories logic (Fienup et al., 2010) was used. The number of story categories inserted in the retelling tasks was measured in each one of the eight sessions to determine if changes in performance occurred with the introduction of visual prompts.

\section{Procedures}

A total of 10 sessions, spread across five weeks, was conducted with each participant. One session was defined as the time between bringing the participants to the experimental setting and returning them to their classroom. Each session lasted 35 minutes on average.

In the first session, participants were brought to the experimental setting to play with some games, do some coloring activities, and talk to the experimenter (rapport establishment).

In the pre and posttests sessions (in which no visual prompts were presented), the experimenter presented the 
instruction: "We are going to listen to a story together. After we listen to the story, you will retell the story to the teddy bear, so pay attention. Can we start?" The experimenter hit the play button on the computer and the story was presented. Then, the experimenter told the participant: "Did you like the story? Let's hear it once more so we can remember everything. Can we start?" After the story was played for the second time, the experimenter went to the back of the classroom, picked up the teddy bear, and placed it on the third chair. Then, the following instruction was issued: "Now, can you tell the story to our friend the teddy bear? He was far away and could not hear the story. Tell him the story, with all the little pieces that you can remember." After the task was completed, the student could color a drawing for up to $5 \mathrm{~min}$.

In the sessions in which visual prompts were presented, the same instruction as in the pre and posttests was presented. However, before the stories were presented, the experimenter placed a visual prompt specific to one of the six story categories on the participant's desk and allowed him to look at the prompt while listening and retelling the story (see Figure 1 for which prompt was presented in which story). The remaining features of the procedure followed those from the pre and posttests. There was no performance criterion linked to the presentation of the next story; however to be considered satisfactory, participant performance in each category had to be $100 \%$ correct (i.e., all categories had to be complete when the story was retold) as described in former studies (Ribeiro et al., 2009; Sella et al., 2013).

\section{Results}

Results on the number of story categories and number of words inserted in the retelling tasks are shown in Figure 2 and Table 1, respectively.

\section{Categories Inserted}

In Figure 2, if participants did not include a given category when retelling a story, they scored zero $(0)$ points; if they included part of the category (e.g., one character instead of all three that were part of the plot), they scored .5 ; if they included the complete category, they scored 1. Overall, the data on insertion of story categories in retelling tasks show no consistent pattern in participants' performance: while some participants inserted the category when presented with a visual prompt once, others inserted the target category in four out of six sessions. Additionally, there were only four instances in which after inserting a complete category for the first time (either before or after the introduction of specific visual prompts), participants' behavior was maintained throughout all of the following retelling tasks. The most consistent data regarding category insertion in retelling tasks refers to the "actions" category: 10 out of the 11 participants inserted this category in the retelling task performed in the session in which this prompt was presented.
Despite the lack of consistency in performance after pictorial prompts were presented, when comparing the data from the pre and the posttest, the results show that 7 out of the 11 participants showed some improvement when pre and posttest results are compared. Scores went from a mean of .864 (range, .0 to 4.0) in the pretest to 2.773 (range, .0 to 5.5 ) in the posttest. Additionally, a pairedsamples $t$-test showed a statistically significant difference $(t(10)=2.23, p=.01)$.

\section{Number of Words Retold Per Total Number of Words}

In regards to the number of words retold, similar results to the ones on categories inserted were found: there was no consistent increase in the number of words retold when pictures were presented, even when the story was comprised of more words. No statistical tests were conducted due to the differences in the total number of words in each story.

\section{Discussion}

The present study adds to the literature by systematically describing and evaluating if 11 first graders would perform better in retelling tasks when pictorial prompts were presented; however no reinforcement was provided for correct responses, and no explicit instructions were provided for using the pictorial prompts.

One interesting aspect of the results refers to the difference in performance in pre ( $\mathrm{H} 0)$ and posttest (H7). During the pretest, three correct responses were emitted across all participants, whereas 28 correct responses were emitted in the posttest (average of 2.5 correct responses per participant in the posttest). Even though this increase in the number of correct category insertion responses cannot be considered satisfactory (i.e., 2.5 correct responses per participant is nowhere near the 6 correct responses that is expected given the literature on teaching complex skills) one could ask why this increase in performance could have occurred since it was not systematic nor consistent. One hypothesis is task exposure. Even though responses in the presence of the pictures were not reinforced, these responses could have increased through exposure to the various story exemplars, which is consistent with the literature about the development of verbal repertoires without direct instruction (e.g., Coon \& Miguel, 2012; Hart \& Risley, 1995; Stokes \& Baer, 1977).

Even though there was a statistically significant performance difference between pre and posttest scores, it is important to highlight that the results were not consistent within and across participants, and do not show significance when a visual analysis is conducted (i.e., clinical significance). Thus, the results indicate that the presentation of visual prompts did not result in consistent increase in performance when the number of story categories inserted after the picture prompt is analyzed. This suggests that (a) the sole presentation of pictorial prompts 
Sella, A. C., Bandini, C. S. M., Bandini, H. H. M., Ribeiro, D. M. \& Vieira, H. C. (2015). Effects of Picture Prompts on Story Retelling Performance in Typically Developing Children.

Kari

$\begin{array}{llllll}\mathrm{C} & \mathrm{S} & \mathrm{T} & \mathrm{P} & \mathrm{A} & \mathrm{R}\end{array}$

Pre $\quad \begin{array}{llllll}1 & 0 & 0 & 1 & 0 & 0\end{array}$

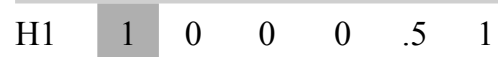

$\mathrm{H} 2 \quad 0 \quad 000011$

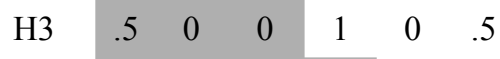

H4 $11 \quad 1 \quad 0011001$

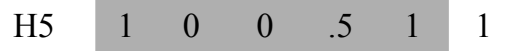

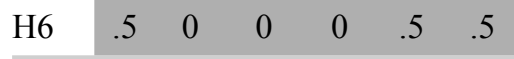

Post $\quad 1 \quad 0 \quad 00 \begin{array}{llll} & 0 & 1 & 1\end{array}$

\section{Mae}

$\begin{array}{lllllll} & \mathrm{C} & \mathrm{S} & \mathrm{T} & \mathrm{P} & \mathrm{A} & \mathrm{R} \\ \mathrm{Pre} & .5 & 0 & 0 & 0 & .5 & .5 \\ \mathrm{H} 1 & 1 & 0 & 0 & .5 & .5 & .5 \\ \mathrm{H} 2 & 0 & .5 & 0 & 1 & 0 & 0 \\ \mathrm{H} 3 & .5 & 0 & 0 & .5 & 0 & .5 \\ \mathrm{H} 4 & .5 & 0 & 0 & 0 & 0 & .5 \\ \mathrm{H} 5 & .5 & 0 & 0 & 0 & 1 & 1 \\ \mathrm{H} 6 & 0 & 0 & 0 & 0 & 0 & .5 \\ \text { Post } & .5 & 0 & 0 & 0 & 0 & 0\end{array}$

Beth

$\begin{array}{lcccccc} & \mathrm{C} & \mathrm{S} & \mathrm{T} & \mathrm{P} & \mathrm{A} & \mathrm{R} \\ \mathrm{Pre} & 0 & 0 & 0 & 0 & 0 & 0 \\ \mathrm{H} 1 & 0 & 0 & 0 & 0 & 0 & 0 \\ \mathrm{H} 2 & 0 & 0 & 0 & 0 & 0 & 0 \\ \mathrm{H} 3 & 1 & 0 & 1 & .5 & 1 & .5 \\ \mathrm{H} 4 & 1 & 0 & 0 & 1 & .5 & 1 \\ \mathrm{H} 5 & 1 & 1 & 0 & 1 & 1 & 0 \\ \mathrm{H} 6 & .5 & .5 & 0 & 1 & 1 & 1 \\ \text { Post } & .5 & 0 & 0 & .5 & 1 & 1\end{array}$

\section{Gigi}

$\begin{array}{llllll}\mathrm{C} & \mathrm{S} & \mathrm{T} & \mathrm{P} & \mathrm{A} & \mathrm{R}\end{array}$

$\begin{array}{lllllll}\text { Pre } & .5 & 0 & 0 & 0 & 0 & 0\end{array}$

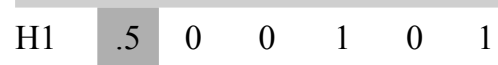

$\begin{array}{lllllll}\mathrm{H} 2 & 1 & 0 & 0 & 1 & 0 & 0\end{array}$

$\begin{array}{lllllll}\mathrm{H} 3 & .5 & 1 & 1 & 0 & 0 & 0\end{array}$

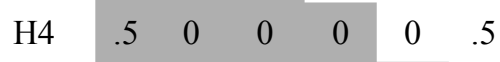

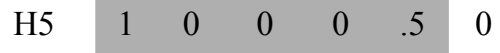

H6 0000000000

Post $0 \begin{array}{llllll}0 & 0 & 0 & 0 & 0\end{array}$

\section{Ron}

$\begin{array}{llllll}\mathrm{C} & \mathrm{S} & \mathrm{T} & \mathrm{P} & \mathrm{A} & \mathrm{R}\end{array}$

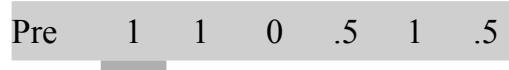

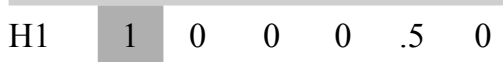

$\begin{array}{lllllll}\mathrm{H} 2 & 0 & .5 & 0 & 1 & 1 & 1\end{array}$

$\mathrm{H} 3 \quad \begin{array}{llllll}.5 & 0 & 0 & .5 & 0 & 1\end{array}$

$\begin{array}{lllllll}\mathrm{H} 4 & 1 & 0 & 1 & 1 & 1 & 1\end{array}$

H5

H6

$\begin{array}{lllllll}\text { Post } & 1 & 1 & 0 & 0 & 1 & 1\end{array}$

Ed

$\begin{array}{llllll}\mathrm{C} & \mathrm{S} & \mathrm{T} & \mathrm{P} & \mathrm{A} & \mathrm{R}\end{array}$

Pre $\quad 0 \quad 0 \quad 000000$

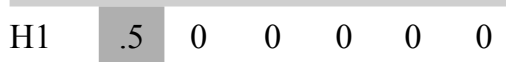

$\begin{array}{lllllll}\mathrm{H} 2 & 1 & .5 & 0 & 1 & 0 & .5\end{array}$

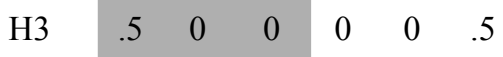

$\begin{array}{lllllll}\mathrm{H} 4 & .5 & 0 & 0 & .5 & 0 & 1\end{array}$

$\begin{array}{lllllll}\mathrm{H} 5 & .5 & 1 & 0 & 0 & 1 & 1\end{array}$

$\begin{array}{lllllll}\mathrm{H} 6 & .5 & 1 & 0 & 0 & .5 & 0\end{array}$

$\begin{array}{lllllll}\text { Post } & .5 & 1 & 0 & 0 & 0 & .5\end{array}$

Mimi

$\begin{array}{llllll}\mathrm{C} & \mathrm{S} & \mathrm{T} & \mathrm{P} & \mathrm{A} & \mathrm{R}\end{array}$

Pre $\quad 0 \quad 0 \quad 00000$

\begin{tabular}{|c|}
\hline H1 \\
\hline
\end{tabular}

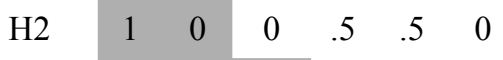

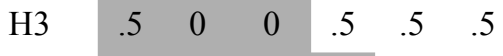

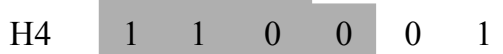

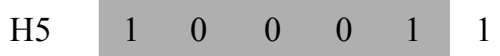

$\begin{array}{lllllll}\mathrm{H} 6 & .5 & 0 & .5 & 1 & .5 & 1\end{array}$

$\begin{array}{lllllll}\text { Post } & 1 & 0 & 0 & .5 & 1 & 1\end{array}$

\section{Ray}

$\begin{array}{llllll}\mathrm{C} & \mathrm{S} & \mathrm{T} & \mathrm{P} & \mathrm{A} & \mathrm{R}\end{array}$

Pre $\quad 1 \quad 0 \quad 000000$

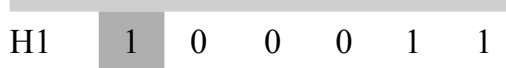

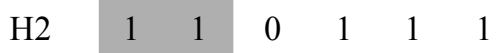

$\begin{array}{lllllll}\mathrm{H} 3 & 1 & 0 & 1 & .5 & 1 & 1\end{array}$

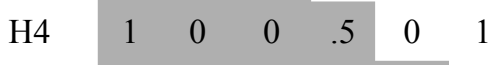

H5

$\begin{array}{lllllll}\mathrm{H} 6 & 1 & .5 & .5 & 1 & 1 & 1\end{array}$

$\begin{array}{lllllll}\text { Post } & 1 & 1 & 1 & 1 & 1 & .5\end{array}$
Cara

$\begin{array}{lcccccc} & \mathrm{C} & \mathrm{S} & \mathrm{T} & \mathrm{P} & \mathrm{A} & \mathrm{R} \\ \text { Pre } & .5 & 0 & 0 & 0 & 0 & 0 \\ \mathrm{H} 1 & 1 & 0 & .5 & 1 & 1 & 1 \\ \mathrm{H} 2 & 1 & 1 & 0 & 0 & 0 & 0 \\ \mathrm{H} 3 & 1 & 1 & 1 & 1 & 1 & 1 \\ \mathrm{H} 4 & 1 & 1 & 0 & 0 & 0 & 1 \\ \mathrm{H} 5 & 1 & 0 & 0 & 0 & 1 & 1 \\ \text { H6 } & 1 & 1 & .5 & .5 & .5 & 1 \\ \text { Post } & 1 & 0 & 1 & 1 & 1 & 1\end{array}$

$\begin{array}{llllll}\mathrm{C} & \mathrm{S} & \mathrm{T} & \mathrm{P} & \mathrm{A} & \mathrm{R}\end{array}$

Pre $\quad 0 \quad 0 \quad 00000$

H1 0000000

H2 0000000

$\begin{array}{lllllll}\mathrm{H} 3 & .5 & 0 & 0 & 0 & 0 & .5\end{array}$

$\begin{array}{lllllll}\mathrm{H} 4 & .5 & 0 & 0 & 0 & 0 & 0\end{array}$

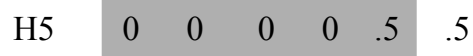

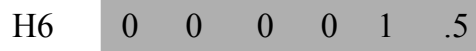

$\begin{array}{lllllll}\text { Post } & .5 & 1 & 0 & 0 & 1 & 1\end{array}$

Sean

$\begin{array}{ccccccc} & \text { C } & \text { S } & \text { T } & \text { P } & \text { A } & \text { R } \\ \text { Pre } & 0 & 0 & 0 & 0 & 0 & 0 \\ \text { H1 } & 0 & 0 & 0 & 0 & 0 & 0\end{array}$

$\mathrm{H} 2 \quad 1 \quad 0 \quad 00000$

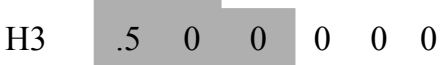

$\mathrm{H} 4 \quad 0 \quad 0000000$

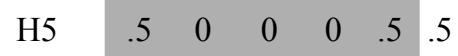

H6 $\quad 0 \quad 0 \quad 000000$

Post $\quad 0 \quad 0 \quad 000000$

Figure 2. Insertion of story categories in each story by participant. 
Table 1

Total Number of Words in Each Story and Number of Words Retold in Each Story by Each Participant

\begin{tabular}{lcccccccc}
\hline & Pretest & H1 & H2 & H3 & H4 & H5 & H6 & Posttest \\
\cline { 2 - 8 } \# of words per story & 169 & 190 & 187 & 190 & 181 & 179 & 145 & 187 \\
\hline Participant & & & \multicolumn{7}{c}{ \# of words retold } & & & \\
Kari & 100 & 80 & 88 & 88 & 93 & 121 & 53 & 95 \\
Mae & 120 & 73 & 115 & 103 & 70 & 77 & 94 & 69 \\
Beth & 0 & 13 & 0 & 110 & 113 & 61 & 94 & 92 \\
Gigi & 26 & 65 & 19 & 42 & 32 & 31 & 3 & 0 \\
Ron & 81 & 32 & 98 & 106 & 99 & 76 & 63 & 60 \\
Ed & 8 & 37 & 33 & 31 & 49 & 77 & 51 & 41 \\
Mimi & 0 & 33 & 61 & 41 & 63 & 68 & 58 & 61 \\
Ray & 23 & 43 & 76 & 99 & 44 & 97 & 53 & 91 \\
Cara & 37 & 90 & 24 & 166 & 79 & 92 & 79 & 139 \\
Aria & 19 & 0 & 0 & 26 & 5 & 10 & 17 & 53 \\
Sean & 12 & 0 & 1 & 20 & 0 & 38 & 0 & 0 \\
\hline
\end{tabular}

does not guarantee performance improvement; (b) these participants did not have a generalized repertoire of using pictures in retelling tasks. These participants would likely benefit from a procedure that aimed at establishing such generalized repertoire. Future studies should investigate which variables are necessary and sufficient to establish a generalized repertoire of retelling stories under the control of visual prompts. A component analysis might be the best way to investigate this phenomenon.

In addition, since pictorial prompts did not seem to directly affect participants' behaviors, it would be interesting to investigate if the repeated exposure to stories itself resulted in this small, but significant change in performance.

\section{References}

Coon, J. T., \& Miguel, C. F. (2012). The role of increased exposure to transfer - of - stimulus - control procedures on the acquisition of intraverbal behavior. Journal of Applied Behavior Analysis, 45, 657-666. doi:10.1901/jaba.2012.45-657

Fienup, D., Covey, D., \& Critchfield, T. (2010). Teaching brainbehavior relations economically with stimulus equivalence technology. Journal of Applied Behavior Analysis, 43, 19-33. doi:10.1901/jaba.2010.43-19.

Frank, A. R., Wacker, D. P., Berg, W. K., \& McMahon, C. M. (1985). Teaching selected microcomputer skills to retarded students via picture prompts. Journal of Applied Behavior Analysis, 18, 179-185. doi:10.1901/jaba.1985.18-179
Gabig, C. S. (2008). Verbal working memory and story retelling in school-age children with autism. Language, Speech, and Hearing Services in Schools, 39, 498-511. doi:10.1044/01611461(2008/07-0023)

Hart, B., \& Risley, T. R. (1995). Meaningful differences in the everyday experience of young American children. Baltimore, MD: Paul H Brookes.

Ingvarsson, E. T., \& Hollobaugh, T. (2011). A comparison of prompting tactics to establish intraverbals in children with autism. Journal of Applied Behavior Analysis, 44, 659-664. doi:10.1901/jaba.2011.44-659

Kail, M., \& Hickmann, M. (1992). French children's ability to introduce referents in narratives as a function of mutual knowledge. First language, 12, 73-94. doi:10.1177/014272379201203405

Liles, B. Z. (1985). Cohesion in the narratives of normal and disordered children. Journal of Speech and Hearing Research, 28, 123-133. doi:10.1044/jshr.2801.123

Lins e Silva, M. E., \& Spinillo, A. G. (2000). The effect of different situations on written stories. Psicologia: Reflexão e Crítica, 13, 337-350. doi:10.1590/S0102-79722000000300003

Mandler, J. M., \& Johnson, N. S. (1977). Remembrance of things parsed: Story structure and recall. Cognitive Psychology, 9, 111-151. doi:10.1016/0010-0285(77)90006-8

McCabe, A., Bliss, L., Barra, G., \& Bennett, M. (2008). Comparison of personal versus fictional narratives of children with language impairment. American Journal of Speech-Language Pathology, 17, 194-206. doi:10.1044/1058-0360(2008/019)

Merritt, D. D., \& Liles, B. Z. (1987). Story grammar ability in children with and without language disorder: Story generation, story retelling, and story comprehension. Journal of Speech and Hearing Research, 30, 539-552. doi:10.1044/ jshr.3004.539 
Sella, A. C., Bandini, C. S. M., Bandini, H. H. M., Ribeiro, D. M. \& Vieira, H. C. (2015). Effects of Picture Prompts on Story Retelling Performance in Typically Developing Children.

Organization for Economic Cooperation and Development. (2013). PISA 2012 Results in Focus: What 15-years-olds know and what they can do with what they know. Washington, DC: Author.

Phillips, C. L., \& Vollmer, T. R. (2012). Generalized instruction following with pictorial prompts. Journal of Applied Behavior Analysis, 45(1), 37-54. doi:10.1901/jaba.2012.45-37

Ribeiro, D. M., Pascualon, J. F., Sella, A. C., Bandini, C. S. M., \& de Souza, D. G. (2009). Avaliação de um programa de ensino de categorias estruturais de histórias para escolares de risco. Revista Semestral da Associação Brasileira de Psicologia Escolar e Educacional, 13, 303-314.

Roberts, G., Good, R., \& Corcoran, S. (2005). Story retell: A fluency-based indicator of reading comprehension. School Psychology Quarterly, 20(3), 304-317. doi:10.1521/ scpq.2005.20.3.304

Secretaria de Educação Fundamental. (1998). Parâmetros curriculares nacionais: Língua Portuguesa. Brasília, DF: Ministério da Educação e Cultura.

Sella, A. C., Ribeiro, D. M., Bandini, C. S. M., Bandini, H. H. M., \& Bomfim, F. M. S. D. (2013). Effects of a teaching program on the discrimination of implicit story categories in children. Psicologia: Reflexão e Crítica, 26(4), 701-710. doi:10.1590/ S0102-79722013000400010

Sparks, A. (2008). The social origins of early literacy: Perspectives from children in Head Start and their families (Doctoral dissertation, Clark University, Worcester, MA, USA), Retrieved from http://search.proquest.com/docview/304674897

Stein, N. L. (1982). The definition of a story. Journal of Pragmatics, 6(5/6), 487-507. doi:10.1016/0378-2166(82)90022-4

Stokes, T. F., \& Baer, D. M. (1977). An implicit technology of generalization. Journal of Applied Behavior Analysis, 10, 349-367. doi:10.1901/jaba.1977.10-349 